\title{
Change in Undisturbed Vegetation on the Coastal Slopes of Subantarctic Macquarie Island, 1980-1995
}

\section{J. B. Kirkpatick and}

\section{J. J. Scott}

School of Geography and

Envionmental Studies, University of Tasmania, Box 252.78. GPO. Hobare

Tasmania 7001: Ausiralia.

J.kirkpatrick@uas.edu.au

\begin{abstract}
The vegetation of 30 undisturbed pemanent quadrats on the steep coastal stopes of subantarctic Macquarie Island was recorded in 1980-81 and 1994--95, a period in which temperatures rose briefly then declined, precipitation increased and rabbil grazing pressure decreased. Previous investigators of the plant cology of the is and have suggested a successional sequence, in the absence of disturbance, towards total dominance of the two major plant species on the coastal slopes, the lall tussock-foming grass Poafoliosa and the megaherb Stilbocarpa polaris, with a concomitant reduction in the diversity of subordinate species. Our observations demonstrate a more complex reality. Densc tall tussock grassland became more open, resulting in an increase in quadrat species richness. The more open tussock grassland on the upper slopes became more dense, with a concomitant decrease in quadrat species richness. The large herb $S$. polaris changed little in its abun. dance over the period, perlaps reflecting a need for disturbance for its cxpansion. The opening of dense stands of $P$. foliosa may be part of a previonsly unrecorded endogenous successional process, while the closure of open stands of Poa could be a response to improved growl conditions, including relief from rabbit grazing and the relatively high temperatures in the initial years of monitoring, bu may also be endogenous in origin.
\end{abstract}

\section{Introduction}

Subantaretic Macquaric Island $\left(54^{\circ} 30^{\prime} S, 158^{\circ} 56^{\circ} \mathrm{E}\right)$ has a cool, moist, and windy climate, and $n$ permanent ice or snow cover due 10 is position immedately norh of the Antartic Polar front. The istand is an elongated phatean rising to a maximum of $433 \mathrm{~m}$. surrounded by an escarpment, or steep coastal shopes, $100 \cdots 250 \mathrm{~m}$ in height. The main plant communities are feldmark. shor grasslind, berbficld, mires, and tall tussock grasshond (Se)kirk el al., 1990).

A substantiat increase in air temperatures occurred on Nacquarie lstand between the late 1940s and the mid 1980 (Fig. 1 ; Adamson of al., 1988; Tweedic and Bergstrom, 2000), a phenomenon also noted for other subantarctic islands (e.g. Smith and Stecnkamp, 1990; Chown and Smith, 1993; Frenot et al., 1997). Howeves, both stmmer and annual temperatures tended to decrease on Macquarie Istand after the mid 1980 high (Fig. 1). Sunmer temperatures show the same tendencies as annual temperatures, while baving a greater vatiation around the meatn (1) 1). The ammal precipitation recorded for Macquarie Island ins steadily increased since the 1970s (Fig. 1). This has also been the case with summer precipiation.

The introduced rabbit, Orotolagus cuniculus, decined in numbers from 150,000 in 1977-78 (Copson et al. 1981) to ap. proximately 50.000 between 1980 and 1984 wibl an average of between 5000 and 15,000 from 1985 to 1994 (Fig. 2; Copson and Whinam, 2001), as a result of the deliberate introduction of myxomatosis and its regular use in subsequen years to control population numbers.

The impact of these environmental changes on the vegetation of the island seems likely to have varied between vegetation types due to factors such as altitude and rabbil habitat prefer. ences (Copson al al., 1981; Copson, 1984: Scot, 1988). vege- tation change has been documented by Scolt $(1985,1995)$ on land slips of various ages on the sicep slopes of the escarpment of the plateau, and by Copson and Whinam (1998) for the midaltitude plateat, two of the man enviromments affected by rabbit grazing. Studies have atso been conlucted along an altitudinal gradient to simulate the effects of climatic waming (Tweedic and Bergstrom. 2000). The control permanent quadrats in the fand slip succession stulies of Scon (1985, 1995), monitored every few years from 1980 anwates, are used in the present paper to detemine vegelation change, relatively independen of the influence of land slips, that took place on the escarpmen of the platcau in the period between 1980-81 and 1994-..95.

The steep coastal slope vegetation is dominated by ciner or both of the tall tussock gass Poa foliosa, and the large-leaved forb Shiboramen polaris, with smaller grasses. forbs, and bryophytes as understory (Taylor, 1955; Selkirk et al. 1990; Scott. 1995). Exceptions are recent land slips, rocky outcrops, and areas of shor grassland on some slopes. Civen that both Poa foliosa and Stilhocapa polaris are caten by rabbits and are capable of foming closed stands, previous investigators have sugested a successional sequence, in the absence of disturbance. towards dominance of these wo species, or towards the ultimate dominance of Poa foliosa (Taytor. 1955: Ashton, 1965; Copson, 1984: Scot, 1985). The complete dominance of one or both of these species could theoretically be expected to reduce the diversity of subordinate species and thus the species richness of the vegetation at the quadrat scale (Comell, 1978).

The permanent quadrats used in the present sudy strowed no signs of disturbance by rabbits or other agents over the period of monitoring. The research was initiated as a latitudinal sudy of succession on hand slips, with the undisturbed quadrats being controls. There were thes no a prori hypotheses on the nature 

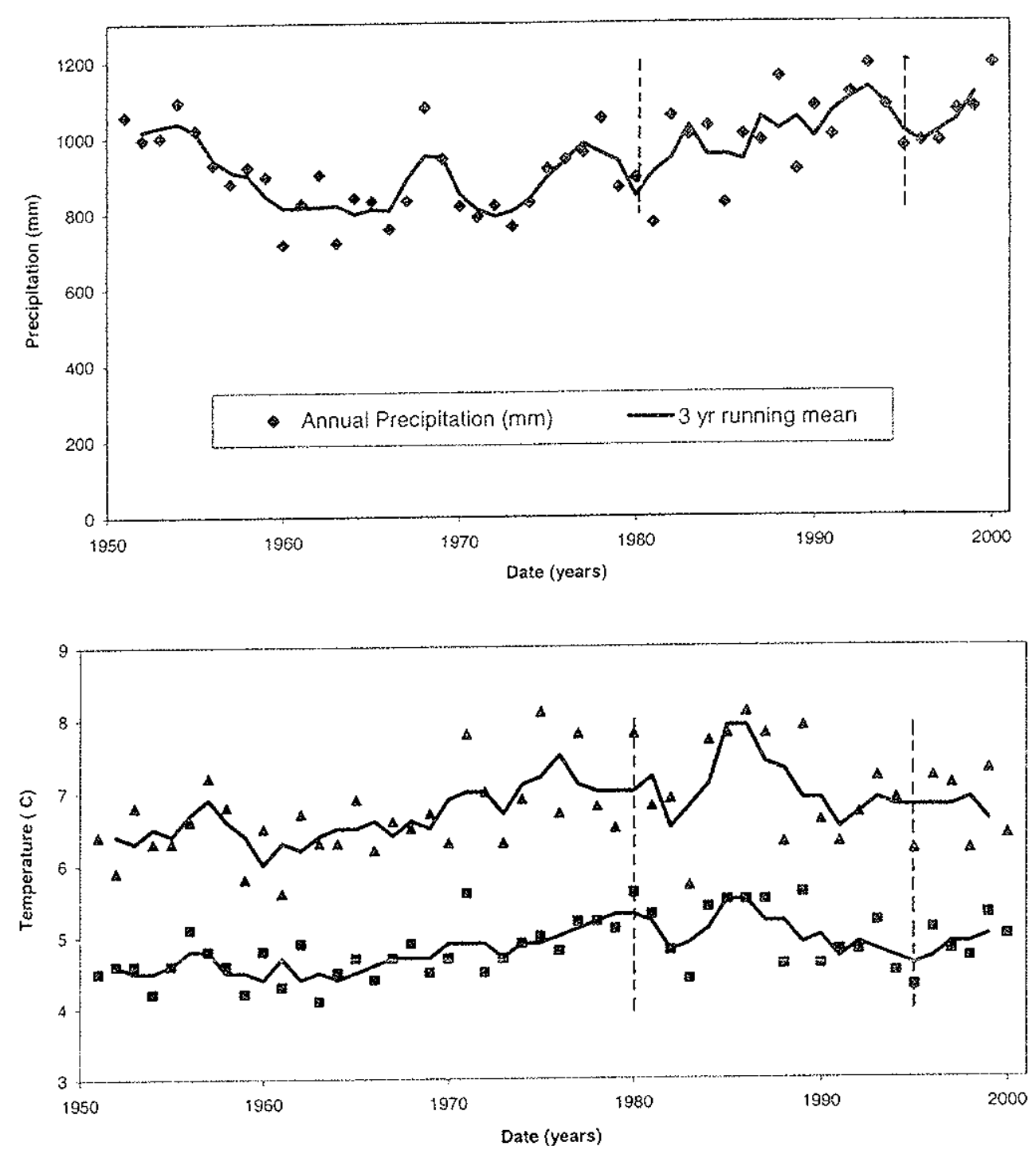

* Mean Annual Temperature 3 yr running mean

- Summer (J,F,M) Mean Temperature - 3 yr running mean

FIGURE I. Changes in annual precipitation, mean annual temperature, and the mean temperature for January, Febratary, and March for Macquarie Island between 1950 and 2000 (Bureau of Meteorology, unpublished). The no vegetation sampling times are shown as dashed vertical lines.

if expected vegetation change in undisturbed vegetation in the nedium term. However, the following a posteriori hypotheses night have been thought appropriate at the time in the context if previous work and ecological theory: directional change in he vegetation over time, increased dominance of Poa foliosa nd/or Stilbocarpa polaris, and decreased species richness at the fuadrat scale.

\section{Methods}

\section{YELD DATA COLLECTION}

In the summer of 1980-81 data from a total of $150,1 \times 1$ n quadrats were collected from the undisturbed vegelation adacent 1050 areas of disturbed vegetation in coastal slope tall ussock grassland. Quadrats were marked with wooden stakes. n the summer of 1994-95 data were collected from a subset of hese quadrats. Because time of the year has an influence on the over of some of the plants in the coastal slope vegetation, the inal selection of permanant quadrats for analysis was restricted to those from which data were recorded in summer (DecemberFebrtary) in both 1980-81 and 1994-95. Permanent quadrats with any signs of rabbit grazing or other disturbance during the time period were excluded. The rabbil signs included scats, burrows and/or obviously grazed plants. Other disturbances includ. ed the collapse of $P$ oa peat pedestals and other mass movement. The number of times that gradrats were revisited between 1980 81 and $1994 \ldots 95$ varied, with all being visited several times beiween the two summers. A total of 30 permanen quadrats were chosen for the ensuing analyses (Fig. 3). The majority are at the southern end of the island, consistent with the retative lack of rabbit grazing clisturbance on coastal slopes in the far south conpared to elsewhere on the island during the monitoring period (Scolt, 1988).

The following data were collected from each quadrat at both times by the one observer. Species abundance was noted using a visually estimated 6-point cover-abundance scale: $1=$ $<1 \% ; 2=<5 \% ; 3=5-20 \% ; 4=20-50 \% ; 5=50-75 \% ; 6=$ $>75 \%$. Species nomenclature of vascular plants follows that of 


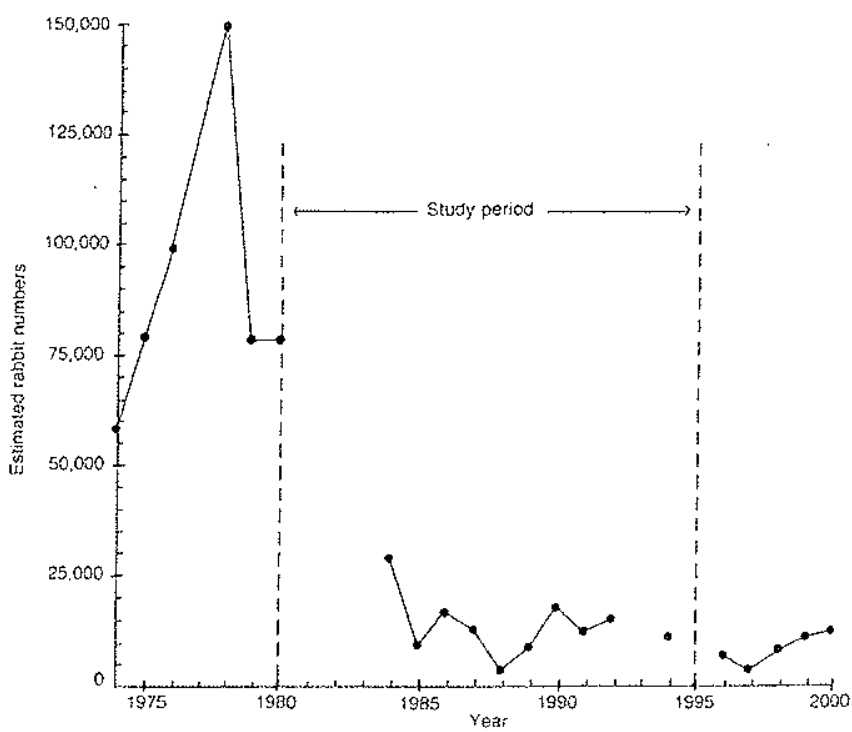

FIGURE 2. Changes in estimated annual rabbit numbers on Macquarie Island 1974-2000 (Copson and Whinam, 2001). The two vegetation sampling times are shown as dashed vertical lines.

Australian Government Publishing Service (AGPS) (1990). Bryophytes were identified to species level where possible (Scott, 1995). Some bryophytes were identified to generic level only (e.g., Metzgeria sp.), or grouped as "spp." if there was a possibility of several species being involved (e.g., Brachythecium spp.). The listing of Megaceros sp. and Riccardia sp. as a single entily, "Megaceros/Riccardia," is an acknowledgment of inconsistent field identification of these species, which both have similar moist habitats. Only one lichen, the foliose taxon Peltigera sp., was recorded. The category "other mosses" included all those mosses which were not identified or were extremely rare.

Mean vegetation height was estimated and placed into the following classes: $1=0-5 \mathrm{~cm} ; 2=6-10 \mathrm{~cm} ; 3=11-30 \mathrm{~cm}$; $4=31-70 \mathrm{~cm} ; 5=71-100 \mathrm{~cm}$. Cover estimates of bare ground and rock were made using the same 6-point scale as for the floristic data.

Data on altitude, aspect, slope, and peat depth were obtained for each quadrat in 1980-81. Altitude was measured approximately using a Thommen 2000 pocket altimeter-barometer. Aspect and slope were measured using a compass and pocket clinometer respectively. Peat depth, excluding litter, was measured by taking three depth measurements per quadrat with a 1 m peat probe and then calculating the mear. The means were placed in the following classes: $1=0-10 \mathrm{~cm} ; 2=11-20 \mathrm{~cm}$; $3=21-50 \mathrm{~cm} ; 4=51-100 \mathrm{~cm} ; 5=>100 \mathrm{~cm}$.

\section{DATA ANALYSIS}

The presence/absence foristic data for the quadrats, comprising both 1980 - 81 and 1994-95 recordings, were converted to an initial sorted table using the polythetic divisive procedure in TWINSPAN (III), 1979). Both the taxa and the quadrats were then resorted by eye, and the resulting rearrangement led to the selection of the four group classification produced by TWINSPAN. Shifts of permanent quadrats from group to group over the monitoring period were recorded.

The foristic abundance data were ordinated using nonmetric multidmensional scaling adopting the default options in DECODA (Minchin, 1991). The direction of movenent of perma-

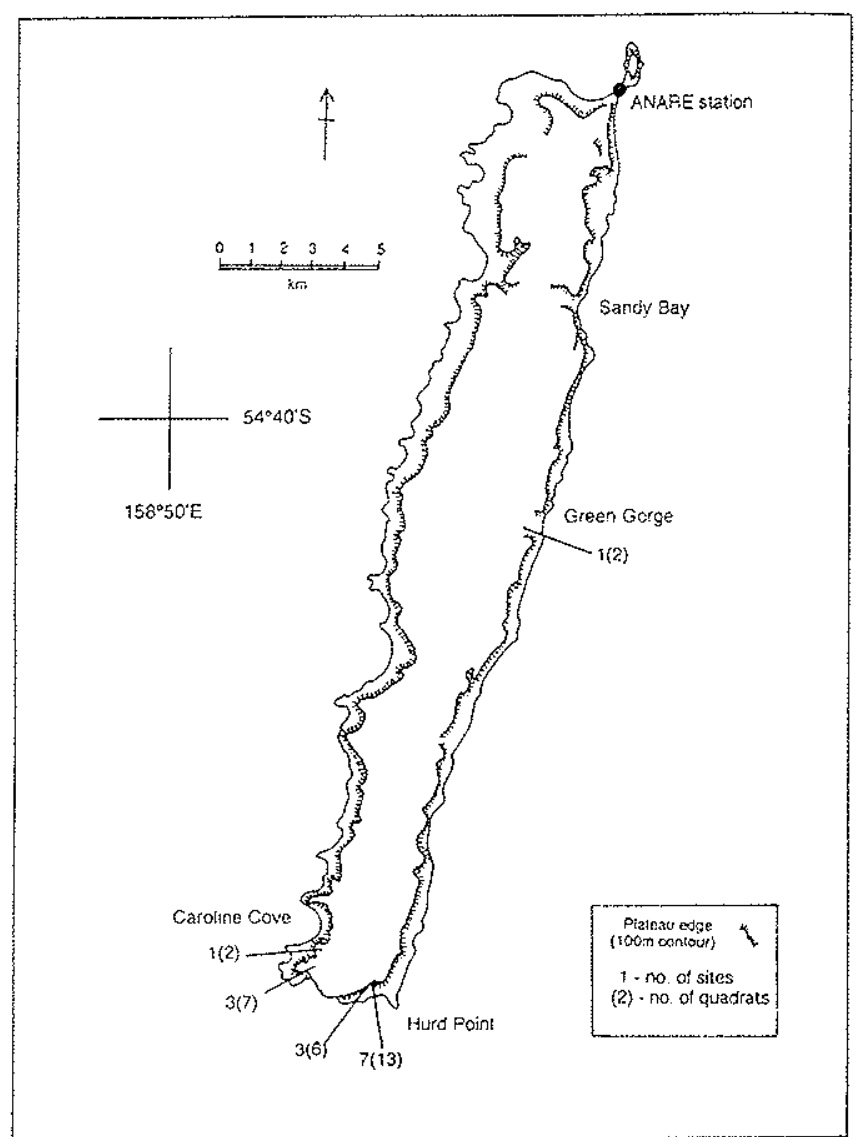

FIGURE 3. Locations of the permanent quadrats on Macquarie Island.

nent quadrats in the ordination space over the measurement period was graphed.

Pearson's product moment correlation coefficient was used to test the significance of linear relationships between environmental and vegetation variables and the abundances of the more frequent taxa. Oneway ANOVA was used to determine the relationships between classificatory groups and environmental and vegetation variables.

Frequency and mean abundance for each species were calculated for the two sels of measurements, and tabulated to show direction of trends in species abundance over the period (increase, decrease, or constant). The number of taxa in each quadrat was counted. This is henceforth called species richness.

\section{Results}

\section{VARIATION IN THE VEGETATION}

Fou classificatory groups were discriminated (Table 1). Poa foliosa and the small leafy liverwort Lophocolea bidentata were almost ubiquitous (Table 1). Poa foliosa increased in dominance through the sequence of communities, apart from Group 2 where Stilbocarpa polaris was codominant. Group I was the richest in species, and had the second lowest stature (Table 2). The most fathful and constant taxa in this community were Sanionia uncinata, Thuidium furfurosum, Breutelia spp., and Epilobium pedunculare, small understory species characteristic of drier shont grassland communities (Scott and Kirkpatrick, 1994) as well as $P$. foliosa-dominated tall tussock vegetation. Festuca contracta, a short grass species which reffects relatively dry warm conditions in the Subantarctic, was more abundant in this 
TABLE I

Sorted table showing the time of data collection and the cover of taxa in quadrats $(\lambda=\langle 1 \% ; 2=1-5 \% ; 3=6-25 \%$; $4=26-50 \% ; 5=51-75 \% ; 6=75 \%$ )

\begin{tabular}{|c|c|c|c|c|}
\hline Colobanthus affinis & $-1-\ldots \ldots$ & $-\cdots-1 \leq-\cdots-1-1-\cdots-1 \hat{1}$ & $-\ldots \ldots \ldots-$ & - \\
\hline Cotuia plumosa & $-\ldots \ldots$ & 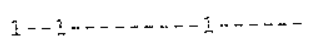 & $---\infty \ldots-n$ & 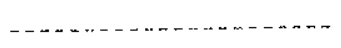 \\
\hline Pleurophyllum hookeri & $--\infty \cdots$ & 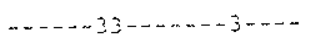 & $\ldots+\cdots-\cdots$ & 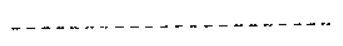 \\
\hline Poa annua & n..- - - - & - n- & 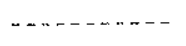 & ג \\
\hline Bryum argenteum & $-\cdots+\cdots$ & $2+\cdots+\cdots+\cdots$ & $-\ldots \ldots+\cdots$ & 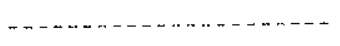 \\
\hline MegacerosiRiccardia & $-\cdots-\cdots$ & $-\ldots+\cdots 1-\ldots \ldots+\ldots-n$ & $-\cdots \cdots--\cdots$ & - \\
\hline Colobanthus muscoides & $-\ldots+\cdots$ & $-i-\cdots \cdots--\cdots+2-\cdots \cdots$ & $n-+-\cdots+-1$ & - \\
\hline Metzgeria sp. & $-\cdots--1$ & $\cdots-211 \cdots+\cdots+\cdots-\cdots+-n \hat{1}-\cdots$ & $\ldots+\ldots+\cdots$ & 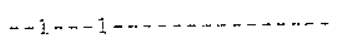 \\
\hline Equitobium brunnescens & $2.2-\cdots--$ & 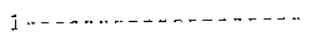 & $\ldots+\cdots---3-\cdots-$ & 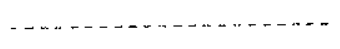 \\
\hline Sanionia uncinata & $-31-34-$ & $2-\cdots-\cdots-2+\cdots+\cdots+\cdots$ & $\ldots-n-\infty-1$ & 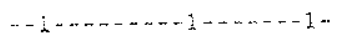 \\
\hline Thuidium furjurosum & $-1 i-111$ & $\cdots-\cdots-2-1-n \ldots-\cdots-\cdots$ & $-\cdots+1-\cdots$ & 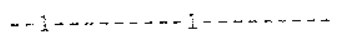 \\
\hline Festuca contracta & $321-333$ & $\hat{\mathbf{i}}--2 \mathrm{i} 133 \mathrm{i}-\hat{\mathbf{i}} \ldots \ldots$ & $\cdots+\cdots$ & - \\
\hline Agrostis magellanica & $331-333$ & $13221133234311-1212-$ & $-\cdots-n l-\ldots-\cdots$ & 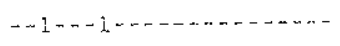 \\
\hline Acaena spp. & 223.2332 & 1. $-111 i 3322-12-1 i i-31$ & $211-112 \cdots--$ & 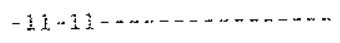 \\
\hline Luzida crinisa & 333.3322 & $1-\cdots+1112222211.11213$ & $--\cdots 1-1 \hat{1}-\cdots+$ & 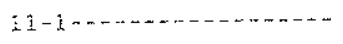 \\
\hline olher mosses & $-1-1 \dot{2} 21$ & $2-1-112-\cdots--1--2-2-$ & $1221 \cdots \cdots+\cdots$ & $1111-1 \cdots-1--\cdots+-1$ \\
\hline Epilobium pedunculare & 2323322 & $---1--2-\cdots \cdots--1--1-1$ & $3231-1.32+-$ & $1122 \ldots \ldots \ldots \ldots$ \\
\hline Peltigera $\mathrm{sp}$ & $1 \ldots \ldots$ & $1-\cdots-1-\cdots-\cdots-1-1-22 \cdots$ & $--21-\cdots-1-2-$ & 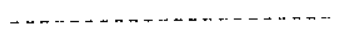 \\
\hline Stilbocarpa polaris & $5-\cdots--4$ & -5345633464441433444 & $\cdots-\cdots 11 \cdots-1-\cdots$ & $-\ldots-33 \ldots+\ldots+-\infty \ldots+\ldots$ \\
\hline Lophocolea bispinosa & $21 \cdots \cdots$ & $2132--1227-221-21332$ & --2222222232 & 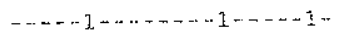 \\
\hline Ranunculus crassipes & 2322222 & $411111123 \div 42321212-2$ & $---22-21 \cdots--$ & $1121 \cdots 1-111 \cdots-11-\cdots-1-\cdots$ \\
\hline Cardamine corymbosa & -111211 & $1.211111-11113.12222$ & 221222.21112 & $11--111-1-11--\frac{1}{2} \cdot 1-\cdots-1-$ \\
\hline Lophocolea bidentata & 21.13221 & $111-11 \pm 121-2122112-1$ & $2321113-222$ & $111112311111 \hat{1} 22111-11 \mathrm{i}$ \\
\hline Pon foliosa & 2466543 & $4-443134324446466545$ & 55566656656 & 5666655666666666666665 \\
\hline Achrophyllum dentatum & $\cdots-\cdots-1$ & $\cdots--\cdots--11--11,-11111$ & $11--1-2122-$ & $11-1-11--111111-11--1-$ \\
\hline Brachythecitum spp. & $-i-\cdots--2$ & $\cdots--\cdots-22 \cdots-1222.32$ & 333212321.21 & $1.1221111212123213231-1$ \\
\hline Bartramia papillata & $3 \cdots \cdots-$ & $2 \cdots \cdots-\cdots 2 i-1-i-1113 . l$ & $--11-11-\cdots 21$ & $-\ldots-\cdots-\cdots 1-\cdots-1--111$ \\
\hline Breutetio spp. & $221222 j$. & 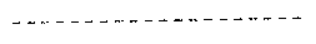 & $2, \cdots 1, \cdots \cdots$ & $1111---1-11-11--1-\cdots$ \\
\hline Stellaria parvifora & $\cdots-\cdots-$ & 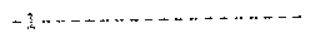 & $\cdots \cdots--1 \cdots-$ & - \\
\hline Marchantia berteroana & $\ldots-n-\infty$ & $2-\cdots \cdots+\cdots--1 \cdots+\cdots+\frac{1}{2}$ & $-\cdots \cdots-\cdots-2$ & 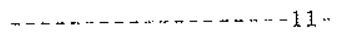 \\
\hline Ceratodon purpureus & $-\ldots \ldots+-$ & $11 \cdots+-\ldots+1, \cdots+\cdots-$ & $-\cdots-1 \cdots-\cdots-1$ & 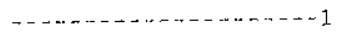 \\
\hline Caltitriche antarctica & $---+\cdots-$ & $1 \cdots \cdots+\cdots \cdots$ & $-\ldots \ldots+\cdots 12$ & $--1-1--+\cdots+-\cdots-\cdots-1$ \\
\hline
\end{tabular}

$1=1980.2=1995$.

community than elsewhere. In Group 1 the relatively high abundance of these understory species reflects a short open $P$. foliosa canopy characteristic of higher altitude coastal slope vegetation.

Group 2 was next richest in species and the second tallest in stature after Group 4 (Table 2). The only largely constant and

\section{TABLE 2}

Mean characteristics of the classificatory groups, showing $P$ values from oneway ANOVA

\begin{tabular}{lcccccc}
\hline & \multicolumn{5}{c}{ Community } \\
& 1 & 2 & 3 & 4 & $P$ \\
\hline Alticude & 89 & 87 & 57 & 58 & 0.056 \\
Aspect (degrees) & 206 & 257 & 149 & 142 & 0.000 \\
Slope (\%) & 31 & 33 & 37 & 33 & 0.257 \\
Peat depth & 3.0 & 3.3 & 3.5 & 3.7 & 0.033 \\
Bare ground & 0.1 & 1.5 & 0.2 & 0.3 & 0.000 \\
Rock cover & 0.0 & 0.1 & 0.1 & 0.1 & 0.729 \\
Vegetation height & 3.7 & 4.1 & 3.5 & 4.7 & 0.000 \\
Species richness & 14 & 12 & 10 & 7 & 0.000 \\
Ordination score axis & 1.10 & 1.24 & 0.56 & 0.32 & 0.000 \\
Ordination score axis 2 & 1.26 & 0.67 & 0.86 & 0.77 & 0.000 \\
\hline
\end{tabular}

- Means of the classes described in the Methods section. faithful species was $S$. polaris (Table 1) which codominated with $P$. foliosa. The moderate frequency of bryophytes such as Achrophyllum dentatum and Brachythecium spp. indicate a slightly moister understory environment than in Group 1. Group 3 was less rich in species and had a shorter statuse than Groups 1 and 2 (Table 2). It had no constant and faithful species, but was intermediate in its composition between Groups 2 and 4. Group 3 had a slightly more open $P$. foliosa canopy and a more abundant and varied understory vegetation than Group 4. Group 4 was the least species rich of the communities with the greatest vegetation height (Table 2 ). It represents the closed $P$. foliosadominated tall tussock grassland vegetation of sheltered lower altitude slopes described by Taylor (1955) and Ashton (1965). It had no constant and faithful species (Table 1). The four groups separated well on the two axis ordination (Table 2).

\section{ENVIRONMENTAL RELATIONSHIPS}

The vegetation groups did not significantly differentiate on altitude or slope (Table 2). There was significant differentiation on aspect, with Groups 1 and 2 occurring on southwest-facing slopes and Groups 3 and 4 on southeast-facing slopes (Table 2). peat depth was significantly differentiated between groups, steadily increasing through the sequence of communities, while 
TABLE 3

Correlations batween enviromental variables, vegetation variables, and the most frequent taxa

\begin{tabular}{|c|c|c|c|c|c|c|c|}
\hline & alt & aspect & $\operatorname{siope}$ & perato & veght & baress & nehness \\
\hline Aspect & 0.477 & $x$ & 0.082 & -0.158 & -0.340 & $0.3 \% 4$ & 0.305 \\
\hline Slope & 0.082 & $\cdots 0.156$ & $X$ & -0.308 & 0.092 & -0.117 & -0.091 \\
\hline Peat depth & -0158 & -0.350 & -0.308 & $x$ & 0.399 & 0.061 & -0.334 \\
\hline Vegetation heigh & -0.340 & -0.607 & 0.092 & 0.399 & $\mathrm{X}$ & -0.214 & $\cdots 0.565$ \\
\hline Bace ground & 0.374 & 0.581 & -0.117 & 0.061 & $\cdots 0.214$ & $x$ & 0.206 \\
\hline Richness & 0.305 & 0.455 & -0.091 & $\cdots 0.334$ & -0.565 & 0.206 & $X$ \\
\hline Agrostis nugellomea & $0.35 \%$ & 0.580 & -0.389 & -0.270 & $\cdots 0.973$ & 0.245 & 0.570 \\
\hline Corkamine corymbost & 0.208 & 0.068 & 0.304 & -0151 & 0.043 & 0.151 & 0.358 \\
\hline Epilotumm pethunculere & 0.152 & $\cdots 0.067$ & 0.085 & $\cdots 0.181$ & $\ldots 0308$ & -0.242 & 0.338 \\
\hline Festuca contucta & 0.129 & 0.383 & -0.346 & -0.284 & -0.563 & 0.057 & 0.506 \\
\hline Lenutios crinita & 0.237 & $0.4 \% 8$ & -0.254 & -0.293 & $\cdots 0450$ & 0.171 & 0.641 \\
\hline Par foliosa & -0.107 & -0.128 & 0.360 & 0.172 & 0.593 & $\cdots 0.401$ & $\cdots 0.429$ \\
\hline Rammoalus crassipes & 0.266 & 0.316 & -0.167 & -0.058 & -0.278 & 0.159 & $0.55 \%$ \\
\hline Achrophyllum denatum & $\cdots 0.243$ & $-1) .137$ & 0.175 & 0.098 & 0.196 & -0.267 & -0.079 \\
\hline Brectiracium spp. & $\cdots 0.259$ & -0.289 & 0.024 & 0.210 & 0.205 & -0.393 & -0.264 \\
\hline Lophorolea bistentuata & $\cdots 0.166$ & -0.266 & 0.055 & 0.042 & 0.028 & -0.245 & 0.123 \\
\hline Lophocolea brspinost & 0.085 & 0.343 & 0.024 & -0.082 & -0.062 & 0.325 & 0.469 \\
\hline Other mosses & 0.138 & 0.087 & 0.019 & -0.220 & -0.241 & 0.105 & 0.434 \\
\hline
\end{tabular}

- Vahes in inalics have a $P$ value of tess than oos.

vegetation height varied but was still significantly differentitted (Table 2). Bare ground was markedly greater in Group 2 than the other communitics (Table 2), a characteristic which has been noted for mixed Poa-Stilbocarpa vegetation (Scot1, 1995). Changes in foristic composition through the community scquence suggest a moisture gradien with communties becoming progressively damper from (iroun 1 to 4 .

Altitude, bare ground, and aspect were positively intercor related (Table 3). Aspect was also negatively related to vegeta. tion height and positively related to species richness ('Tble 3 ). Species richness was positively related to aspect and negatively related to vegetation height, while vegelation height was positively related to peat depth (Table 3 ).

Significant corretatons between the more abundant taxa and enviromental variables (Table 3 ) are as follows. Only one of the more abundant taxa, Acaena spp.. was significantly correlated with altude, occuring preferentially at higher elevations (Table 3). Acaena spp., Agrostis magellanica. Festuca contracta. luzula crinta, and Stibocarpa polaris were positively associared with aspect, occurring more on souhwesterly slopes, while Foa foliosa had the reverse relationstrip, occuring more on southeasterly slopes. Poa foliosa occurred more abundanty on stecper slopes, white A. magellanica preferred shallower slopes. Poa foliosa and Brachythecium spp. were negalively corretated with bare ground, while S. polaris was posilively correlated. None of the more abundant laxa had a significant relationship

TABLE 4

Transitions between classificatory groups $1980 \ldots 1995$

\begin{tabular}{|c|c|c|c|c|}
\hline \multirow{2}{*}{$\begin{array}{c}\text { Croup } \\
(1994-1995)\end{array}$} & \multicolumn{4}{|c|}{ Ciroup (1980) 1981 ) } \\
\hline & 1 & 2 & 3 & 4 \\
\hline 1 & 1 & 1 & $\cdots . .$. & 3 \\
\hline 2 & j & 7 & $\ldots$ & 1 \\
\hline 3 & $\ldots \ldots$ & 2 & $\ldots$ & 7 \\
\hline 4 & $\ldots . \cdot$ & 1 & 2 & 4 \\
\hline
\end{tabular}

with peat depth. Vegetation height was positively correlated with Poa foliosa abundance, and negatively comelated with deacna spp., A. magellanica. F contracta, L. crinta, and S. polaris abundances. Species richness was negatively correlated with $P$. foliosa abundance and positively correlated with abundance of Acaena spp.. A. magellanica, Cardanine corymbosa. F. conracta, Lophocolea bispinosa, L. crinita, other mosses, Ramuculus crassipes, and $S$. polaris.

\section{THE: ANT WOGTATION VAR/ATIOA}

Groups 2 and 4 had more $1980-81$ quadrats than $1994-95$ quadrats. white Groups 1 and 3 had only two 1980-.81 quadrats each (Table 1), signifying a shift in vegetation communily characteristics lowards the latter two communities. The tansition matrix (Table 4) shows that most of the change in community composition resulted from 11 quadrats in Group 4 shifting to Groups 1, 2. and 3 in 1995, mainly to Group 3. Overall, 12 quadrals shifted in the direction of Group 1, of towards the drier end of the vegetation continum, while 6 quadmats shifted in the other direction towards (nroup 4 , or the moister end of the conlimum (Table 4).

Of the 11 quadrats that moved from Group 4 , wine had increased species richness in 1994-95, one was constam. and only one had decreased species richness. This contrasts with the general situation, in which 12 of the permanen quadrats decreased in species richness over the monitoring period and 18 were constan or increased. In only three of the quadrats that shifted from Group 4 did the major dominam Poa foliosa increase or maintain is cover ln eight quadians its cover decreased. Concomitant with this decline in abundance of $P$. foliosa, there were consistent increases in the cover of Acaena spp. Cartamine corymbosa. Epilobiun pedunculare, Luata crinita. Brachythecium spp., Lophocolea bidentata, L. bispinosa, and other mosses.

Poa foliosa increased or mantained its cover in 19 of the 30 quadrats and decreascd in abundance in 11 quadrats over the 35-yr period. In 9 of these 11 quadrats species nichness increased 
TABLE 5

Changes in percentage frequency (f) and mean abundance scores (a) for taxa 1980-81 and 1994-95. showing direction of change

\begin{tabular}{|c|c|c|c|c|c|c|}
\hline & $\begin{array}{c}f \\
1980\end{array}$ & $\begin{array}{c}a \\
1980\end{array}$ & $\begin{array}{c}\mathrm{f} \\
1995\end{array}$ & $\begin{array}{c}a \\
1995\end{array}$ & f & $a$ \\
\hline Brytim argenteum & 3.3 & 0.1 & 0.0 & 0.0 & -- & - \\
\hline Póa annua & 3.3 & 0.0 & 0.0 & 0.0 & $\cdots$ & - \\
\hline Pieurophylum hookeri & 3.3 & 0.1 & 6.7 & 0.2 & $\dot{+}$ & + \\
\hline Enitobium brunnescens & 3.3 & 0.0 & 10.0 & 0.2 & -4 & + \\
\hline Hypnum sp. & 3.3 & 0.0 & 0.0 & 0.0 & - & - \\
\hline Wegaceros/Riccardia & 3.3 & 0.0 & 0.0 & 0.0 & - & - \\
\hline Stellaria parviffora & 3.3 & 0.0 & 3.3 & 0.0 & $\overline{=}$ & $=$ \\
\hline Colobanthus affunis & 6.7 & 0.1 & 16.7 & 0.2 & $t$ & 4 \\
\hline Callitricine antarctica & 10.0 & 0.1 & 6.7 & 0.1 & - & - \\
\hline Cotula plumosa & 10.0 & 0.1 & 0.0 & 0.0 & $\cdots$ & - \\
\hline Colobanthus muscoides & 10.0 & 0.1 & 3.3 & 0.0 &. & - \\
\hline Marchantia berteroana & 13.3 & 0.2 & 10.0 & 0.1 & - & - \\
\hline Peltigera sp. & 13.3 & 0.1 & 23.3 & 0.4 & + & $\div$ \\
\hline Cerastium fontanum & 16.7 & 0.2 & 3.3 & 0.0 & - & - \\
\hline Ceratodon purpureus & 16.7 & 0.2 & 3.3 & 0.0 & - & - \\
\hline Thuidium furfurosum & 16.7 & 0.2 & 16.7 & 0.2 & $=$ & $\underline{-m}$ \\
\hline Sanionia uncinata & 20.0 & 0.2 & 13.3 & 0.4 & - & + \\
\hline Fistuca contracta & 20.0 & 0.3 & 26.7 & 0.6 & + & + \\
\hline Metzgeria sp. & 2.3 .3 & 0.3 & 0.0 & 0.0 & - & - \\
\hline Breutelia sp. & 26.7 & 0.3 & 36.7 & 0.6 & $\div$ & + \\
\hline Epilobium pedunculare & 30.0 & 0.4 & 43.3 & 1.0 & + & + \\
\hline Bartramia papillata & 30.0 & 0.3 & 43.3 & 0.6 & + & 4 \\
\hline Lophocolea bispinosa & 36.7 & 0.6 & 6.3 .3 & 1.3 & + & + \\
\hline Achrophyllum dentalum & 40.0 & 0.4 & 63.3 & 0.7 & $\therefore$ & + \\
\hline Stilbocarpa polaris & 43.3 & 1.6 & 43.3 & 1.5 & $=$ & - \\
\hline Luzula crinita & 43.3 & 0.5 & 60.0 & 1.1 & - & + \\
\hline Acaena spp. & 46.7 & 0.6 & 63.3 & 1.2 & - & + \\
\hline Agrostis magellanica & 50.0 & 0.8 & 43.3 & 1.0 & - & + \\
\hline Other mosses & 53.3 & 0.6 & 30.0 & 0.4 & - & - \\
\hline Brachythecitum spp. & 63.3 & 0.8 & 76.7 & 1.6 & + & + \\
\hline Ranunculus crassipes & 76.7 & 1.1 & 60.0 & 1.2 & - & + \\
\hline Cardamine corymbosa & 80.0 & 0.9 & 73.3 & 1.0 & - & $\dot{r}$ \\
\hline Lophocotea bidentata & 93.3 & 1.1 & 90.0 & 1.5 & - & 4 \\
\hline Poa foliosa & 96.7 & 4.9 & 100.0 & 5.0 & + & f- \\
\hline
\end{tabular}

over the measurement period. The one quadrat in which species richness decreased was one of only two quadrats in which Stilbocarpa polaris increased its cover over the time period. Species richness dccreased or remained constant over the time period in 12 of the 19 quadrats in which $P$. foliosa increased or maintained its cover. Mean quadrat species richness increased from 9.0 to 12.2 where $P$. foliosa decreased in cover, while it decreased from 10.5 to 9.2 in those quadrats in which $P$. foliosa maintained or increased its cover. In the three quadrats in which $S$. polaris decreased in cover over the time period species richness increased, from a mean of 8.7 to a mean of 11.3 . Where $S$. polaris remained constant (eight quadrats) or increased in cover (two quadrats), there was a decline in species richness in five quadrats and constancy or increase in five quadrats. The mean quadrat species richness for quadrats with $S$. polaris declined from 12.1 in 1980 to 11.5 in 1995 .

While overall mean quadrat species richuess increased from 9.97 to 10.27 in the period $1980-81$ to $1994-95$, the total number of species recorded in all quadrats declined from 33 to 27 (Table 5). Taxa which disappeared were Bryum argenteum and Poa annua (botl commonly associated with bare ground and disturbance), Hypnum sp., Megaceros/Riccardia, Cotula plumosa, and Metzgeria sp.

Sixteen of the 18 permanent quadrats with scores of 0.75

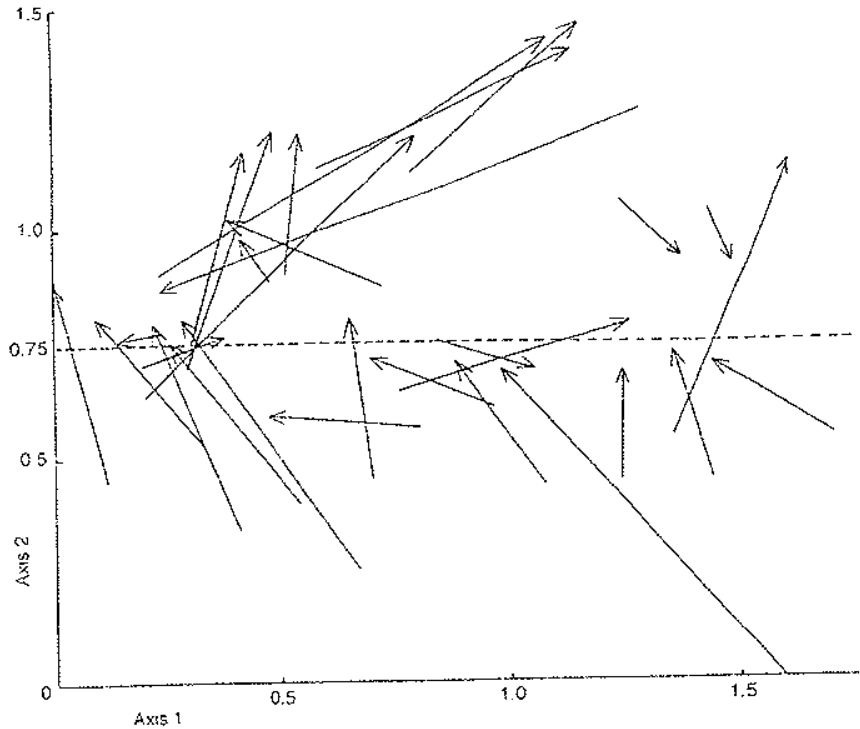

FIGURE 4. Movement of permanent quadrats in floristic ordination space. The arrows extend from the 1980 location to the 1995 location, which is marked by their head. The line at 0.75 on axis 2 marks the upper value at which all permanent quadrats share the same direction.

or less on axis 2 in 1980 had higher scores in 1995 than 1980 (Fig. 4), indicating strong directional change over time in this sector. Seven of the 12 permanent quadrats with scores greater than 0.75 on axis 2 in 1980 also had higher scores in 1995 (Fig. 4).

The vascular plants that increased most dramatically in boch mean cover and frequency between the two measuring times were Colobanthus affinis, Festuca contracta, L. crinita, Epilobium pedunculare, E. brunnescens, and Acaena spp. (Table 5). In addition, 6 of the 14 nonvascular taxa (Peltigera sp., Breutelia sp., Bartramia papillata, L. bispinosa, Achrophyllum dentatum, and Brachythecium spp.) showed strong increases (Table 5). The introduced Cerastium fontanum was the only vascular plant species to decrease markedly in both cover and frequency (Table 5). One nonvascular plant, Metzgeria sp., exhibited a similarly marked decrease (Table 5). The prevailing dominant, $P$. foliosa, slightly increased both its frequency and cover, in contrast to the other major dominant of the coastal slopes, $S$. polaris, which maintained its frequency but slightly decreased in cover (Table 5).

\section{Discussion}

Environmental variation has a strong relationship with variation in the species composition and structure of the escarpment vegetation sampled in this study. The association of peat depth with floristic composition and vegetation height is particularly strong (Tables 2, and 3). The independence of peat depth from the other measured environmental variables (Table 3) indicates that the vegetation responses might partly refiect long term factors of slope stability such as different periods since the last land slip. Land slips are frequent on the steep vegetated slopes as a result of seismic activity and heavy rainfall events (Scott, 1988). Slope instability may be inevitable in this environment given progressive peat accumulation (Selkirk et al, 1990). The nature of the vegetation change with increasing peat depth is consistent with the successional sequence on land slips documented by Scott (1985). The relatively high cover of bare ground in the 
species-rich Group 2 (Table 2) and in quadrats in which Stil. bocarpa polaris was present (Table 3), and the low levels of bare ground where poa foliosa was most abundant (Table 3), is also consistent with this posited successional sequence. The statistically strong role of aspect in infuencing vegetation variation is likely to be an artifact of the locations of the permanent quadrats.

The shift in foristic composition of permanent quadrats on axis 2 in the ordination space (Fig. 4) indicates highly consistent directional variation in the vegetation between 1980-81 and 1994-95, particularly in the sector of axis 2 below 0.75 , which includes Groups 2 and 4 (Fig. 4). This directional change occurs in all parts of the environmentally related contintum, which is reflected roughly by scores on axis 1 . Nevertheless, the degree and nature of the change varied between those permanent quadrats that were relatively species rich in 1980 and contaned $S$. polaris (mostly Group 2), and those that were relatively species poor in 1980 and were dominated almost totally by $P$. foliosa (mostly Group 4). The former group of quadrats experienced a lesser degree of change than the Iatter, many of which shifted markedly in the vegetation continuum (Table 4), with a decline in the abundance of $P$. foliosa and an associated increase in species richness.

The ecological dominance of $P$. foliosa and $S$. polaris is apparent in the strong increases in the richness of other species with a decline in either or both of their abundances, compared to a mean decrease in species richness in quadrats in which they remained constant or increased in cover.

The expected increase in cover of $P$. foliosa was somewhat subdued (Table 5). Increases in abundance which occurred where it had relatively low cover were almosi compensated for by some decreases in abundance where it had relatively high cover. Some of the opening out of the $P$. foliosa tussock grassland may result from the senescence of long-established indiviouals, uncompensated by establishment of new seedlings or thizomatous spread. Seedlings of $P$. foliosa have not been recorded in long-undisturbed vegetation, although they have been noted from revegetating land slips (Scott, 1995).

Like $P$. foliosa, S. polaris failed to increase in dominance, a superficially surprising result given its known positive response to exclusion from grazing by fencing (Scott, 1995; Copson and Whinam, 1998). However, the criteria for selection of undisturbed sites in 1980 implied that the vegetation inclucled in the present study was not in the early successional stages after disturbance. The lack of response of $S$. polaris to environmental change in later successional stages suggests that soil disturbance may be a prerequisite for its establishment (Scott, 1995), that it is not highly competitive with $P$. foliosa in closed communitics, and that $P$. foliosa is not highly competitive with it. There is little evidence of the posited cyclic succession between $P$. foliosa and S. polaris (Astion, 1965) in the data from the permanent quadrats. In only 1 of the 10 quadrats in which there was a decrease in cover of Poa foliosa was there an associated increase of cover in $S$. polaris. In no quadrat was there an increase of $P$. foliosa with a decrease in $S$. polaris.

Thus, of our hypotheses, we can confirm only directional change in the vegetation with time. Increased dominance of $P$. foliosa and/or S. polaris, and decreased species richness at the quadrat scale either did not occur or occurred in only a subset of the quadrats. In reality $S$. polaris clanged minimally and two sets of quadrats behaved very differently. Those with intial low cover of $P$. foliosa gained more cover of the species, with a conconitant tendency towards a reduction in species richness, while those with an initially high cover of Poa foliosa lost cover of the species, with a concomitant increase in species richness.

There is widespread and justifiable concern that the nature and distribution of terrestrial subantarctic ecosystems is changing with global waming (e.g., Tweedie and Bergstrom, 2000). However, climatic change is not strongly indicated as a cause of most of the vegetation changes we have documented. Temperatures on Macquarie Island in the late 1980 s and early 1990s were similar to those recorded in the 1960 s (Fig. 1). However, the historically very high summer and annual temperatures recorded for the mid 1980 s (Fig. 1) might have been partially responsible for increases in the cover of $P$. foliosa in the subset of quadrats in which it did increase in cover. It is difficult to relate this warm period to the decrease in cover of $P$. foliosa in the other subset. The steady increase in anmal precipitation from the early $1970 \mathrm{~s}$ to the early 1990s (Fig. 1) seems unlikely to have markedly influenced the changes given that the shifts in floristic composition were weighted towards the drier end of the vegetation continuum, unless there was a decline in peat depth caused by increased rainfall. Increased erosion seems unlikely given the drizzly nature of Macquarie Island precipitation and was not observed. Any increase in peat breakciown rates as a consequence of possibly higher levels of cyclic salts seems likely to have been more than compensated for by reduced breakdown rates as a consequence of lower temperacures.

There seems little doubt that a reduction in rabbit grazing pressure has resulted in increases in cover of $P$. foliosa and $S$. polaris, where previously sparse, on parts of Macquarie Island (Copson and Whinam, 1998), but this relationship camot explain the observed reduction in the cover of $P$. foliosa where it was initially high in cover, and the constancy in cover of $S$. polaris. There is also a possibility that those escarpment sites with no rabbit grazing between 1980--81 and 1994-..95, may also have been ignored by rabbits in earlier years (Scott, 1988).

Our observations strongly suggest the existence of a previously unrecorded late successional stage on the escarpment, involving a reduction in $P$. foliosa cover and slagnation in the cover of $S$. polaris. This change may reflect sencscence of the $P$. foliosa tussocks and the absence of its regeneration, and lack of regeneration of $S$, polaris, without disturbance. The increase in $P$. foliosa cover where it was initially relatively low was an expected part of the succession, which may have been inftuenced in its rate by either, or both of, a reduction in rabbit grazing pressure, and initially high temperatures during the monitoring period.

\section{References Cited}

Adamson, D. A., Whetion, P., and Selkirk, P. M., 1988: An analysis of air temperature records for Macquarie Island: decadal warming, ENSO cooling and southern hemisphere circulation patterns. Papers and Proceedings of the Royal Society of Tasmania, 122: 107-112.

Ashton, D. H., 1965: Regeneration pattern of Poa foliosa Hook. f. on Macquarie Istand. Proceedings of the Royal Society of Victoria, 79: 215-233.

Australian Government Publishing Service (AGPS), 1990: Census of Australion Vascular Plants: Australian Flora and Fauna Series, 11. Canberra: AGPS. $650 \mathrm{pp}$.

Chown, S. L. and Smith, V. R., 1993: Climate change and the short-erm impact of feral house: mice at the sub-Antarctic Prince Edward Islands. Oecologia, 96: 508-..516.

Connell, J. H., 1978: Diversity in tropical rainforests and corál reefs. Science, 199: 1302-1330.

Copson, G. R., 1984: An amotated atlas of the vascular flora of 
Macquarie Island. ANARE Research Notes, 18. Antarctic Division, Department of Science and Technology. $70 \mathrm{pp}$.

Copson, G. R., Brotbers, N. P., and Skira, L. J., 1981: Distribution and abundance of the rabbit, Oryctolagus cuniculus (L.) at subantarctic Macquarie Island. Australian Wildlife Research, 8: $597-611$.

Copson, G. R. and Whinam, J. J., 1998: Response of vegetation on subantarctic Macquarie Island to reduced rabbit grazing. Australian Journal of Botany, 46: 15-24.

Copson, G. R. and Whinam, J. J., 2001: Revicw of ecological restoration programme on subantarctic Macquarie Island: pest management progress and future directions. Ecological Management and Restoration, 2: 129-138.

Frenot, Y., Gloaguen, J. C., and Trehen, P. 1997: Climate change in Kerguelen Islands and colonization of recently deglaciated areas by Poa kerguelensis and $P$. annua. In Battaglia, B., Valencia, J., and Walton, D. W. H. (eds.), Antarctic Communities: Species, Structure and Survival. Cambridge: Cambridge University Press: $358-366$.

Hill, M. O., 1979: TWINSPAN: a Fortran program for arranging multivariate data in an ordered two-way table by classification of the individuals and attributes. Cornell University; New York.

Minchin, P. R., 1991: DECODA User's Manual. ANUTECH, Canberra.

Scott, J. J., 1985: Effects of feral rabbits on the revegetation of disturbed coastal slope sfies, Macquarie Island. MA thesis, Monash University, Melbourne. 219 pp.

Scott, J. J., 1988: Rabbit distribution history and related land disturbance, Macquarie Island. Papers and Proceedings of the Royal Society of Tasmania, 122: 255-263.

Scott, J. 3., 1995: Changes in vegetation on Macquarie Island coastal slopes, 1980-1990. Ph.D. thesis, University of Tasmania, Hobart. 340 pp.

Scott, J. J. and Kirkpatrick, J. B., 1994: Effects of human trampling on the sub-Antarctic vegetation of Macquarie Island. Polar Record, 30: 207-220.

Selkirk, P. M.. Seppelt, R. D., and Selkirk, D. R., 1990: Subantarctic Macquarie Island: Environment and Biology. Cambridge: Cambridge University Press. $285 \mathrm{pp}$.

Smith, V. R. and Steenkamp, MI., 1990: Climatic change and its ecological implications at a subantarctic island. Oecologia, 85: $14-24$.

Taylor, B. W., 1955: The flora, vegetation and soils of Macquarie Island. ANARE Report, Ser. B (2):19. Antarctic Division, Department of Science and Technology. $192 \mathrm{pp}$.

Tweedie, C. E. and Bergstrom, D. M., 2000: A climate change scenario for surface air temperatures at Subantarctic Macguarie Island. In Davison, W., Howard-Willians, $C$., and Broady, P. (eds.), Antarctic Ecosystems: Models for Wider Understanding. New Zealand Natural Science, Canterbury University, Christchurch, 272-281.

Ms submitted September 2001 